\title{
ANALISIS ASESMEN PROYEK DALAM PEMBELAJARAN PKN BERORIENTASI PENDIDIKAN NILAI TERHADAP SIKAP SOSIAL DAN HASIL BELAJAR PADA SISWA KELAS VIII SMP NEGERI 6 SINGARAJA
}

\author{
Desak Putu Parmiti \\ Program Studi Pendidikan Guru Sekolah Dasar, Universitas Pendidikan Ganesha \\ Email:dskpt_parmiti@yahoo.co.id \\ Ndara Tanggu Rendra \\ Program Studi Pendidikan Guru Sekolah Dasar, Universitas Pendidikan Ganesha \\ Email: ndaratanggu.renda@undiksha.ac.id
}

\begin{abstract}
Abstrak
Tujuan penelitian ini adalah (1) menganalisis perbedaan secara bersama-sama sikap sosial dan hasil belajar antara kelompok siswa yang diberikan APMKN dan kelompok siswa yang diberikan MPK; (2) menganalisis perbedaan sikap sosial siswa antara kelompok siswa yang diberikan asesmen proyek dalam pembelajaran PKn berorientasi pendidikan nilai (APMKN) dan kelompok siswa yang diberikan model pembelajaran konvensional (MPK); dan (3) menganalisis perbedaan hasil belajar antara kelompok siswa yang diberikan (APMKN) dan kelompok siswa yang diberikan MPK. Penelitian ini merupakan kuasi eksperimen. Data yang dikumpulkan adalah sikap sosial dengan angket sikap sosial, dan hasil belajar PKn dengan tes. Teknik analisis data yang digunakan adalah statistik deskriptif dan statistik inferensial MANOVA satu jalur. Hasil penelitian menunjukkan (1) terdapat perbedaan yang signifikan sikap sosial dan hasil belajar PKn secara bersama-sama antara kelompok siswa yang diberikan APMKN dan kelompok siswa yang diberikan MPK; (2) terdapat perbedaan yang signifikan sikap sosial antara kelompok siswa yang diberikan APMKN dan kelompok siswa yang diberikan MPK. Hasil belajar PKn kelompok siswa yang diberikan APMKN lebih tinggi dibandingkan dengan siswa yang diberikan MPK; dan (3) terdapat perbedaan yang signifikan hasil belajar PKn antara kelompok siswa yang diberikan APMKN dan kelompok siswa yang diberikan MPK. Kepada Guru PKn, disarankan mencoba menerapkan asesmen proyek dalam pembelajaran teknik klarifikasi nilai pada pembelajaran PKn.
\end{abstract}

Kata-kata kunci: asesmen proyek, pendidikan nilai, sikap sosial, hasil belajar PKn

\begin{abstract}
The aimed this research are (1) to analyze the differences social attitudes and learning outcomes between groups of students who are given assessment project in the model values clarification (APMKN) and groups of students who are given the conventional learning model (MPK) together; (2) analyze the differences in social attitudes of students between groups of students who are given assessment project in Civics learning the value of education (APMKN) and student groups who are given conventional learning model (MPK); (3) analyze the differences in learning outcomes between groups of students who are given APMKN and student groups who are given MPK. This is a quasi-experimental study. Data which are collected is questionnaire social attitudes for social attitudes, and learning outcomes Civics with the test. Data analysis technique which is used is descriptive and one way inferential statistics MANOVA. The results shows that (1) there is a significant difference of social attitudes and learning outcomes Civics between groups of students who are given APMKN and groups os student who are given MPK; (2) there is a significant difference between the social attitudes of groups of students who are given $A P M K N$ and groups of students were given the MPK. The Civics study result of groups of students who are given APMKN is higher than the group of students who are given MPK; and (3) there is a significant difference in Civics learning outcomes between groups given APMKN students and groups of students are given MPK. To Civics teachers are recommended trying to implement a project assessment in learning value clarification technique in learning Civics.
\end{abstract}

Keywords : project assessment, value education, social attitude, Civics study result

\section{Pendahuluan}

Permasalahan penting yang dihadapi oleh dunia pendidikan adalah mengupayakan peserta didik yang tidak hanya cerdas, tetapi juga berkarakter. Untuk mewujudkan hal tersebut, diperlukan pendidikan karakter (Adisusilo, 2012). Pendidikan karakter harus ditujukan untuk memenuhi pemenuhan kebutuhan internasional tanpa melupakan kebutuhan nasional. Pendidikan karakter harus berorientasi kepada penciptaan keunggulan kompetitif dan keunggulan komparatif. Keunggulan kompetitif dicapai dengan pendidikan karakter berbudaya keselamatan. Sedangkan keunggulan komparatif dicapai dengan penanaman wawasan kebangsaan. Dua hal tersebut diperlukan untuk menjawab dan memenuhi persyaratan kompetensi internasional serta meningkatkan daya saing bangsa dalam era globalisasi.

Pendidikan karakter sangat sejalan dengan penanaman pendidikan nilai di sekolah. Penanaman pendidikan nilai merupakan bagian dari tugas pendidikan nasional, yaitu suatu proses pemanusiaan manusia. Hal tersebut sangat penting demi berlangsungnya optimalisasi perkembangan harkat dan martabat kemanusiaan itu sendiri. Manusia tidak dengan sendirinya 
memanusia, seperti binatang membinatang dengan sendirinya (Dantes, 2012). Manusia memerlukan sentuhan mendasar untuk bisa menjadi manusia. Melalui pendidikan, proses pemanusiaan itu terjadi. Dalam kaitan dengan hal tersebut, Ki Hadjar Dewantara menyatakan bahwa Tri Pusat Pendidikan merupakan lembaga pendidikan yang dapat menumbuhkan, mengembang-kan dan membina akal budi berkembang menjadi optimal sesuai dengan nilai-nilai luhur bangsa. Melalui pendidikan keluarga, masyarakat dan sekolah hal itu akan tercapai. Didasari pada akal budi yang luhur, akan muncul perilaku (pekerti) yang adab (sopan, santun, menghargai sesama). Oleh karena itu, sangat diperlukan generasi bangsa yang memiliki budi pekerti luhur terlebih-lebih dalam menghadapi dunia global yang penuh dengan tantangan. Hal itu akan dapat tercapai, apabila pendidikan tidak melupakan penanaman nilai.

Salah satu bentuk pendidikan yang banyak menyentuh nilai luhur dan moral bangsa adalah Pendidikan Kewarganegaraan (PKn). Mata Pelajaran Pendidikan Kewarganegaraan merupakan mata pelajaran yang memfokuskan pada pembentukan warga negara yang memahami dan mampu melaksanakan hak-hak dan kewajibannya untuk menjadi warganegara Indonesia yang cerdas, terampil, dan berkarakter yang diamanatkan oleh Pancasila dan UUD 1945 (Zuriah, 2008).

Untuk mencapai tujuan tesebut, pembelajaran PKn hendaknya dikemas dengan sedemikian rupa agar sesuai dengan karakteristiknya yaitu penanaman nilai. Dengan demikian, pembelajaran PKn dapat meningkatkan kualitas diri yang tercermin dari sikap dan perilaku siswa dalam kehidupan sehari-hari.

Namun kenyataannya, berdasarkan observasi dan wawancara dengan guru SMP yang mangampu mata pelajaran PKn di Kota Singaraja, tampaknya pelaksanaan pembelajaran PKn masih sedikit bergeser dari harapan pemerintah. Dapat dirasakan pendidikan kewarganegaraan masih hanya sekadar ilmu pengetahuan yang hanya dihafalkan tanpa ada pemahaman dan pemaknaan terhadap nilai yang dipelajari sehingga belum terjadi peningkatan kualitas diri sebagai manusia dalam diri siswa itu sendiri. Penekanan makna dan pemahaman terhadap nilai dalam proses pembelajaran masih jarang dilakukan oleh pihak pengajar. Proses pembelajaran dalam mata pelajaran PKn juga masih banyak yang dilakukan dengan model atau metode yang konvensional sehingga berimbas pada masih rendahnya kualitas pembelajaran. Pembelajaran yang demikian kurang dapat menyentuh aspek hati nurani peserta didik. Dampaknya dapat dilihat dari banyaknya di kalangan generasi muda yang berperilaku menyimpang, seperti mabuk-mabukan, tawuran, pergaulan bebas, dan sebagainya.

Masalah seperti itu sebenarnya dapat diminimalisir apabila guru lebih memahami pentingnya pendidikan nilai dan guru dapat lebih kreatif dalam merancang suatu pembelajaran yang dapat memaksimalkan kualitas belajar siswa. Guru bisa menerapkan model pembelajaran inovatif yang disertai penggunaan evaluasi yang mengukur aspek kognitif dan psikomotor, tidak sebatas aspek kognitif saja. Salah satu model penting dalam pendidikan nilai adalah model valuesclarification (klarifikasi nilai). Menurut Kirshenbaum dalam Lasmawan (2005), menyatakan bahwa "Value Clarification Technique yang selanjutnya disingkat VCT adalah salah satu model pembelajaran inovatif yang menekankan pada pemahaman nilai sosial, budaya, personal, dan masyarakat". VCT adalah model pembelajaran khusus yang dapat diterapkan pada mata pembelajaran PKn untuk memberikan pemahaman yang lebih jelas tentang suatu nilai. Nilai (value) merupakan hal mendasar yang bersifat mulia dan universal yang ada pada diri seseorang. Secara garis besar, Linda (dalam Elmubarok, 2009) nilai dibedakan menjadi dua kelompok, yaitu nilai-nilai nurani (values of being) dan nilai-nilai memberi (values of giving). Nilai-nilai nurani meliputi: kejujuran, keberanian, cinta damai, keandalan diri, dan lain-lain. Sedangkan nilai-nilai memberi meliputi: setia, dapat dipercaya, hormat, cinta, dan lain-lain. Selanjutnya, Linda (1995) mendefinisikan pendidikan nilai adalah penanaman dan pengembangan nilai-nilai pada diri seseorang.

Dalam praktik pembelajaran, pendidikan nilai diterapkan melalui beberapa pendekatan pendidikan nilai, seperti pendekatan penanaman nilai, pendekatan perkembangan kognitif, pendekatan analisis nilai, pendekatan pembelajaran berbuat, dan pendekatan klarifikasi nilai (Elmubarok, 2009). Di antara pendekatan pendidikan nilai tersebut, salah satu yang tepat diterapkan untuk anak SMP adalah pendekatan klarifikasi nilai yang sering juga disebut teknik klarifikasi nilai (TKN). Tahapan-tahapan pembelajarannya adalah sebagai berikut (Raths, et. al., 1987). (1). Pengenalan dan Pemahaman (Identifikasi dan Eksplorasi). Pada tahap ini, melakukan eksplorasi terhadap nilai-nilai yang dimiliki oleh siswa. (2) Memilih (choosing). Pada tahap ini, iswa mengeksplorasi keluasan sistem nilai yang dimilikinya, menilik diri dalam menentukan mana sistem nilai keyakinannya yang menguntungkan dan mana yang merugikan dirinya baik secara pribadi, sosial, maupun religius. Siswa juga mencari dan menemukan sumber-sumber informasi nilai yang umum diyakini orang, khususnya orang-orang berarti, dan mendiskusikannya bersama guru. (3) Menghargai (prizing). Pada tahap ini, guru mengkondisikan siswa agar mereka merasakan atau meyakini atas rasa bahagia atau gembira dengan pilihannya (nilai yang dianut dari masalah yang dipilih secara klasikal). (4) Bertindak (acting). Pada tahap ini, berbuat sesuatu dengan pilihannya, siswa membuat keyakinan nilai secara tegas dan mencoba berbuat serta berinteraksi menurut sistem nilai pilihannya yang telah ditetapkan secara berkelompok ataupun personal, dan pilihan nilai (kesimpulan atas masalah) bisa dilakukan pengulangan dengan penekanan beberapa konsep oleh guru untuk melihat dan memunculkan suatu pola tingkah laku dalam hidup di masyarakat (harapan pola kehidupan yang diidamkan). (5) Refleksi dan Evaluasi. Pada tahap ini, membuat refleksi diri terhadap pilihan nilainya, pengalaman yang dirasakan, apakah siswa merasa nyaman dengan pilihan nilainya. Guru melakukan penilaian akhir dengan meminta siswa untuk melakukannya secara personal ataupun kelompok, sehingga siswa merasakan adanya penghargaan atas nilai yang dianutnya. Dengan menggunakan model ini, pendidik/guru tidak secara langsung menyampaikan kepada peserta didik tentang "benar" atau "salah", tetapi sebaliknya peserta didik harus diberikan kesempatan untuk menyatakan nilai-nilai dengan caranya sendiri.

Selain model pembelajaran yang digunakan oleh guru, asesmen juga memegang peranan penting dalam keberhasilan pembelajaran. Asesmen yang dilakukan hendaknya berkelanjutan untuk perbaikan pada proses pembelajaran. Hal ini sejalan dengan mata pelajaran PKn merupakan mata pelajaran yang berkaitan dengan nilai, maka hendaknya diperhatikan evaluasi yang tepat digunakan. Selama ini, berdasarkan pengamatan dan diskusi dengan beberapa guru-guru PKn SMP di Kota Singaraja, diketahui bahwa asesmen yang digunakan pada umumnya asesmen konvensional (pencil and paper test). Penggunaan asesmen konvensional hanya dapat mengukur aspek kognitif siswa, sedangkan aspek afektif kurang dapat dicermati. Untuk mengukur aspek afektif siswa diperlukan asesmen alternatif. Salah satu asesmen alternatif yang dapat digunakan mengukur aspek afektif adalah asesmen proyek. Asesmen proyek merupakan jenis asesmen autentik. Asesmen 
proyek mengamanatkan keterampilan dan kemampuan yang dibutuhkan untuk melaksanakan tugas yang sesungguhnya. Sehubungan dengan hal tersebut, dipandang sangat perlu dikaji tentang penerapan asesmen proyek dalam pembelajaran PKn berorientasi pendidikan nilai.

\section{Metode}

Penelitian ini mengikuti desain penelitian kuasi eksperimen dengan rancangan non-equivalent post test only control group design. Populasi dalam penelitian ini adalah siswa kelas VIII SMP Negeri 6 Singaraja tahun pelajaran 2014/2015 sebanyak sepuluh kelas. Seluruh kelas memiliki tingkat kesetaraan yang sama. Hal ini didasarkan atas asumsi bahwa tidak ada kelas unggulan. Dengan kata lain, seluruh kelas adalah kelas paralel. Dari sepuluh kelas tersebut dipilih empat kelas sebagai sampel penelitian. Pengambilan sampelnya menggunakan teknik random sampling. Setelah didapat empat kelas, selanjutnya dipilih dua kelas sebagai kelompok eksperimen, dan dua kelas lainnya sebagai kelompok kontrol. Pemilihan sampel dalam penelitian dilakukan tanpa pengacakan individu. Cara ini dipilih karena sulit merubah kelas yang sudah terbentuk. Berdasarkan karakteristik populasi dan tidak bisa dilakukannya pengacakan individu.

Data yang dikumpulkan dalam penelitian ini adalah sikap sosial dan hasil belajar PKn. Data sikap sosial dikumpulan dengan menggunakan angket, sedangkan data hasil belajar PKn dikumpulkan dengan tes. Analisis statistik yang digunakan untuk menguji hipotesis adalah MANOVA satu jalan. Sebelum melakukan analisis MANOVA satu jalan, terlebih dahulu dilakukan pengujian normalitas dan homogenitas (Candiasa, 2007). Normalitas sebaran data mengunakan statistik Kolmogrov Test dan Shapiro-Wilks Test. Kriteria pengujian: data memiliki sebaran distribusi normal jika angka signifikansi yang dihasilkan lebih besar dari 0,05 dan dalam hal lain data tidak berdistribusi normal. Uji homogenitas menggunakan Levene's test of Equality of Error Variansce. Kriteria pengujian: data memiliki varians yang sama (homogen) jika angka signifikansi yang diperoleh lebih besar dari 0,05 dan dalam hal lain varians sampel tidak sama (tidak homogen). Uji prasyarat dan uji hipotesis ini dilakukan dengan bantuan SPSS Statistics 17.0. Semua pengujian hipotesis dilakukan pada taraf signifikansi $5 \%$.

\section{Hasil dan Pembahasan}

Sebelum dilakukan uji hipotesis, terlebih dahulu dilakukan uji prasyarat, yaitu menentukan normalitas dan homogenitas data tiap kelompok. Berdasarkan analisis data diketahui bahwa semua data baik kelompok yang diberikan asesmen proyek dalam Model Klarifikas Nilai (APMKN)) maupun Model Pembelajaran Konvensional (MPK) untuk data Sikap Sosial (SS), dan Hasil Belajar (HB) terdistribusi normal dengan nilai-nilai statistik Kolmogorov-Smirnov dan atau Shapiro-Wilk menunjukkan angka-angka dengan taraf signifikansi lebih besar dari 0,05. Demikian pula untuk homogenitas data, semua nilai statistik Levene menunjukkan angka signifikansi di atas 0,05 . Hal ini berarti, varians antar kelompok model pembelajaran adalah homogen. Mengingat data hasil penelitian telah memenuhi persyaratan normalitas dan homogenitas varians, maka multivariate analisis of varian (MANOVA) satu jalanr dapat dilanjutkan.

Berdasarkan analisis data dengan melakukan uji hipotesis pada penelitian ini, terungkap hasil penelitian sebagai berkut. Pertama, berdasarkan sumber pengaruh model pembelajaran diperoleh nilai-nilai statistik Pillai's Trace, Wilk's Lambda, Hotelling's Trace, dan Roy's Largest Root masing-masing dengan F = 4,303 dan angka signifikansi masing-masing 0,009. Angka signifikasi tersebut lebih kecil dari 0,05. Hasil ini dijadikan dasar dalam mengambil keputusan. Adapun keputusannya adalah hipotesis nol yang menyatakan "tidak ada pengaruh model pembelajaran terhadap sikap sosial dan hasil belajar secara bersama-sama", ditolak. Jadi, variasi model pembelajaran memberikan dampak berbeda serempak pada sikap sosial dan hasil belajar.

Kedua, berdasarkan sumber pengaruh variabel Model Pembelajaran (MP) terhadap variabel terikat sikap sosial (SS), diperoleh nilai statistik $F=4.504$ dengan angka signifikansi 0,038. Angka signifikansi ini lebih kecil dari 0,05. Dengan demikian dapat dinyatakan bahwa terdapat perbedaan nilai rata-rata sikap sosial antara kelompok APMKN dan kelompok MPK. Perbandingan nilai rata-rata kelompok APMKN dan kelompok MPK disajikan pada Tabel 1.

Tabel 1. Perbadingan Nilai Rata-rata Sikap Sosial

\begin{tabular}{|c|c|c|}
\hline Aspek & APMKN & MPK \\
\hline Nilai Rata-rata & 145.667 & 138.233 \\
\hline
\end{tabular}

Di samping itu, nilai $\Delta \mu$ (SS) $==7,433$ lebih besar dari LSD (SS) $=7,005$. Jadi, nilai rata-rata sikap sosial kelompok APMKN dan kelompok MPK berbeda secara signifikan pada taraf signifikansi 0,05. Rata-rata nilai SS kelompok APMKN secara statistik lebih tinggi dibandingkan dengan nilai rata-rata kelompok MPK. Ini berarti sikap sosial yang dicapai oleh siswa yang diberikan asesmen proyek dalam model klarifikasi nilai lebih baik dibandingkan dengan siswa yang diberikan model pembelajaran konvensional.

Ketiga, berdasarkan sumber pengaruh variabel model pembelajaran (MP) terhadap variabel terikat HB, diperoleh nilai statistik $F=4.639$ dengan angka signifikansi 0,035. Angka signifikansi ini lebih kecil dari 0,05. Dengan demikian dapat dinyatakan bahwa terdapat perbedaan yang signifikan nilai rata-rata hasil belajar antara kelompok APMKN dan kelompok MPK. Perbandingan nilai rata-rata kelompok APMKN dan kelompok MPK disajikan pada Tabel 2.

Tabel 2. Perbadingan Nilai Rata-rata Hasil Belajar

\begin{tabular}{|c|c|c|}
\hline Aspek & APMKN & MPK \\
\hline Nilai Rata-rata & 75.70 & 68.70 \\
\hline
\end{tabular}


Di samping itu, nilai $\Delta \mu(\mathrm{HB})==7,000$ lebih besar dari LSD $(\mathrm{HB})=6,417$. Jadi, rata-rata nilai hasil belajar kelompok siswa yang belajar mengikuti APMKN secara statistik lebih tinggi dibandingkan dengan nilai rata-rata kelompok siswa yang belajar mengikuti MPK. Ini berarti hasil belajar yang dicapai oleh siswa yang diberikan asesmen proyek dalam model klarifikasi nilai lebih baik dibandingkan dengan siswa yang diberikan model pembelajaran konvensional.

Hasil penelitian menunjukkan bahwa terdapat perbedaan yang signifikan sikap sosial dan hasil belajar PKn antara kelompok siswa yang diberikan asesmen proyek melalui pembelajaran TKN dan kelompok siswa yang belajar dengan model pembelajaran konvensional. Sikap sosial kelompok yang diberikan asesmen proyek melalui pembelajaran TKN lebih tinggi dibandingkan dengan kelompok model pembelajaran konvensional. Dengan kata lain, bahwa asesmen proyek melalui pembelajaran TKN berpengaruh terhadap peningkatan sikap sosial siswa. Tetapi, secara deskriptif level sikap sosial siswa ini belum maksimal (masih dalam kategori tinggi).

Meskipun penelitian ini konsisten dengan teori-teori yang ada, namun terdapat dua pertanyaan yang memerlukan pembahasan lebih lanjut terkait dengan pencapaian skor sikap sosial siswa. Pertama, secara operasional emperis mengapa dalam pencapaian sikap sosial, asesmen proyek melalui model pembelajaran TKN lebih unggul daripada model pembelajaran konvensional. Kedua, mengapa secara statistik deskriptif asesmen proyek melalui model pembelajaran TKN dalam pencapaian sikap sosial belum mampu mencapai kategori sangat tinggi.

Pembahasan atas pertanyaan pertama beranjak dari komparasi secara teoretik dan operasional empiris antara asesmen proyek malalui model pembelajaran TKN dan model pembelajaran konvensional. Dasar filosofis pembelajaran TKN adalah paham konstruktivisme yang menyatakan bahwa pebelajar membangun pengetahuan/sikapnya sendiri. Paham konstruktivisme juga menyatakan bahwa pebelajar telah memiliki pengalaman awal yang mereka peroleh dari pengalaman sehari-hari dan jenjang pendidikan sebelumnya. Guru dapat menjembatani antara pengalaman awal siswa dengan pengetahuan ilmiah yang akan dibelajarkan. Keadaan ini dapat dimisalkan dengan guru menyediakan tangga yang dapat membantu siswa untuk mencapai tingkatan sikap perilaku yang diharapkan, namun harus diupayakan agar siswa sendiri yang memanjat tangga itu.

Di lain pihak, model pembelajaran konvensional diawali dengan penyajian materi pelajaran yang terkait oleh guru kepada siswa. Teori, konsep, ataupun prinsip-prinsip PKn yang diharapkan dapat dikuasai oleh siswa dipaparkan terlebih dahulu di depan kelas oleh guru. Setelah itu, barulah siswa dihadapkan pada permasalahan-permasalahan yang terkait dengan konsep yang telah dipaparkan. Permasalahan yang disampaikan kepada siswa sama dengan permasalahan yang digunakan dalam pembelajaran TKN, yaitu masalah-masalah aktual yang ada di lingkungan sekitar siswa (kontekstual). Penyajian masalah kontekstual ini menjadikan pembelajaran PKn lebih bermakna dibandingkan dengan hanya membaca ataupun mendengarkan penjelasan guru mengenai materi pelajaran. Namun, dalam model pembelajaran konvensional yang menyuguhkan permasalahan kepada siswa setelah mereka diberikan informasi-informasi tentang materi pembelajaran dinilai kurang konstruktivis. Tanggung jawab siswa terhadap pembelajaran dirinya sendiri menjadi kecil, sebab siswa belajar hanya semata-mata karena guru memberikan tugas kepada siswa untuk mempelajari materi ajar tersebut. Hal ini akan mengurangi kemandirian siswa dalam belajar untuk mengkonstruksi sikapnya sendiri sehingga berdampak pada kebiasaan yang menyebabkan sikap sosial siswa menjadi lebih rendah.

Berdasarkan deskripsi landasan operasional teoretik tersebut, dapat dipahami bahwa model pembelajaran TKN lebih unggul dibandingkan dengan model pembelajaran konvensional dalam pencapaian sikap sosial siswa. Di samping itu, penelitian ini juga sejalan dengan penelitian-penelitian sebelumnya. Kalih (2011) dalam penelitiannya menyimpulkan bahwa model pembelajaran TKN dan sikap sosial sangat berpengaruh terhadap hasil belajar pendidikan kewarganegaraan. Sundara (2008) dalam penelitiannya berkaitan sikap sosial mengungkapkan bahwa terdapat hubungan dan determinasi yang signifikan antara pemahaman nilai-norma-moral pancasila, sikap sosial, dan motivasi berprestasi baik secara sendiri-sendiri maupun simultan terhadap hasil belajar mata pelajaran PKn. Umbara (2011) dalam penelitiannya menyimpulkan bahwa asesmen dan sikap sosial mempunyai pengaruh terhadap prestasi belajar IPS.

Satu persoalan lagi yang perlu diberikan penjelasan, mengapa secara statistik deskriptif model pembelajaran TKN dalam pencapaian sikap sosial belum dapat mencapai kategori sangat tinggi. Berdasarkan landasan teori tersebut, seyogyanya model pembelajaran TKN dapat diakomodasi oleh semua siswa, sehingga perolehan skor sikap sosial siswa mencapai kriteria keberhasilan yang maksimal. Tetapi kenyataannya, skor rata-rata sikap sosial siswa pada kelompok model pembelajaran TKN hanya berkategori tinggi dan belum mampu mencapai kategori sangat tinggi. Terungkapnya fakta seperti ini diduga kuat disebabkan oleh tiga faktor.

Pertama, bertitik tolak dari landasan konseptual pembelajaran yang berorientasi konstruktivisme, bahwa siswa mampu mengkonstruksi pengetahuan/pengalaman dengan alokasi waktu yang sifatnya pribadi. Artinya, dalam upaya pembentukan sikap diperlukan kurun waktu yang berbeda antara satu siswa dengan siswa lainnya.

Kedua, para siswa belum terbiasa dengan aktivitas belajar sesuai dengan tuntutan skenario pembelajaran. Interaksi antar siswa berada pada level rendah, sebagai akibat kurangnya pembentukan sikap sosial. Interaksi yang terjadi justru mengakibatkan terjadinya rasa malu pada diri siswa atau takut melakukan aktivitas. Di samping itu, siswa belum memiliki keterampilan yang baik melakukan diskusi, bertanya, dan menjawab pertanyaan temannya. Walaupun tidak semua siswa dapat meningkatkan kemampuan diskusinya secara spontan, namun minimal mereka sudah melakukan aktivitas yang diinginkan sesuai prosedur pembelajaran tersebut.

Ketiga, bersumber dari pengukuran. Siswa belum terbiasa dengan soal yang mengukur asfek sikap. Di samping itu, dengan tingkat kesukaran tes dan alokasi waktu yang disediakan untuk menjawab, belum sepenuhnya mengakomodasi kemampuan siswa. Artinya, waktu yang diperlukan oleh siswa untuk menjawab tes tersebut masih kurang. Hal tersebut juga berimplikasi pada rubrik yang digunakan untuk penskoran, sehingga tuntutannya menjadi terlalu tinggi. Terkait dengan hal ini, untuk pelaksanaan penelitian lebih lanjut perlu adanya pertimbangan ke arah penggunaan bentuk tes yang lain.

Pencapaian hasil belajar PKn siswa kelompok yang diberikan asesmen proyek melalui pembelajaran TKN lebih tinggi dibandingkan dengan kelompok model pembelajaran konvensional. Dengan kata lain, bahwa asesmen proyek melalui pembelajaran TKN lebih unggul dibandingkan dengan model pembelajaran konvensional dalam pencapaian hasil belajar PKn. 
Hasil penelitian ini konsisten dengan penelitian-penelitian yang dilakukan sebelumnya. Penelitian yang dilakukan Sudiana (2010) juga mengungkapkan bahwa metode pembelajaran TKN dapat meningkatkan prestasi belajar PKn. Metode pembelajaran PKn memberikan hasil yang lebih dibandingkan dengan metode pembelajaran konvensional. Sarapung (2010) juga mengungkapkan dalam penelitiannya bahwa hasil belajar agama Kristen meningkat setelah diterapkan model pembelajaran VCT dan siswa memberikan respons positif terhadap penerapan model pembelajaran VCT. Hal sejenis juga diungkapkan oleh Winata (2010). Dalam penelitiannya yang berjudul pengaruh implementasi teknik klarifikasi nilai (TKN) dan motivasi berprestasi terhadap hasil belajar PKn pada siswa kelas V SD gugus 1 Mendoyo Kapupaten Jembrana-Bali terungkap bahwa terdapat perbedaan hasil belajar PKn antara kelompok siswa yang belajar dengan TKN dan kelompok siswa yang belajar mengikuti model konvensional. Hasil belajar siswa lebih baik yang belajar mengikuti model TKN dinadingkan siswa yang belajar dengan model konvensional

\section{Simpulan}

Berdasarkan hasil penelitian dan pembahasan, maka dapat diuraikan simpulan sebagai berikut. (1) Terdapat perbedaan yang signifikan sikap sosial dan hasil belajar PKn secara bersama-sama antara kelompok siswa yang diberikan asesmen proyek dalam pembelajaran teknik klarifikasi nilai dan kelompok siswa yang diberikan dengan model pembelajaran konvensional. (2) Terdapat perbedaan yang signifikan sikap sosial antara kelompok siswa yang diberikan asesmen proyek dalam pembelajaran teknik klarifikasi nilai dan kelompok siswa yang diberikan model pembelajaran konvensional. Hasil belajar PKn kelompok siswa yang diberikan asesmen proyek dalam pembelajaran teknik klarifikasi nilai lebih tinggi dibandingkan dengan siswa yang belajar dengan model pembelajaran konvensional. (3) Terdapat perbedaan yang signifikan hasil belajar PKn antara kelompok siswa yang diberikan asesmen proyek dalam pembelajaran teknik klarifikasi nilai dan kelompok siswa yang belajar dengan model pembelajaran konvensional. Hasil belajar PKn kelompok siswa yang diberikan asesmen proyek dalam pembelajaran teknik klarifikasi nilai lebih tinggi dibandingkan dengan siswa yang belajar dengan model pembelajaran konvensional.

Berdasarkan hasil penelitian yang telah disimpulkan di atas, dapat disarankan hal-hal sebagai berikut. (1) Mengingat pembelajaran PKn sangat memperhatikan sikap sosial siswa selain kemampuan kognitifnya, maka guru disarankan mencoba menerapkan asesmen proyek dalam pembelajaran teknik klarifikasi nilai pada pembelajaran PKn. Melalui nilai yang dikembangkan pada diri siswa, dirahapkan nantinya siswa menjadi pribadi yang lebih baik. (2) Asesmen proyek dalam pembelajaran teknik klarifikasi nilai diharapkan dapat diterapkan untuk mata pelajaran lain, seperti pendidikan agama, budi pekerti, dan lainnya. Hal ini penting dilakukan untuk memperluas penggunaan asesmen proyek pada pembelajaran teknik klarifikasi nilai yang telah terbukti efektif meningkatkan hasil belajar PKn. (3) Mengingat keterbatasan penelitian ini, dirahapkan peneliti lain melakukan penelitian sejenis untuk meningkatkan sikap sosial dan hasil belajar PKn siswa. Ada beberapa hal yang perlu diperhatikan, antara lain: waktu penelitian agar lebih lama, mengembangkan model asesmen penanaman nilai yang tepat untuk siswa, dan melakukan penilaian autentik.

\section{Daftar Pustaka}

Candiasa, I M. 2004. Statistik Multivariat Dilengkapi Aplikasi dengan SPSS. Singaraja: Unit Penerbitan IKIP Negeri Singaraja.

Dantes, N. 2012. "Perspektif dan Kebijakan Pendidikan Menghadapi Tantangan Global." Makalah, Disampakaian pada Pelatihan Dosen Muda Undiksha, 5 Nopember.

Elmubarok, Z. 2009. Menumbuhkan Pendidikan Nilai: Mengumpulkan yang Terserak, Menyambung yang Terputus, dan Menyatukan yang Tercerai. Bandung: Alfabeta.

Kalih, I K. 2011. "Pengaruh Implementasi Teknik Klarifikasi Nilai (TKN) Terhadap Hasil Belajar Pendidikan Kewarganegaraan Ditinjau dari Sikap Sosial Siswa (Studi Eksperimen pada Siswa Kelas VIII SMP Negeri 3 Negara).” Tesis, Universitas Pendidikan Ganesha.

Lasmawan, W. 2004. "Pengembangan Model Pendidikan Berdemokrasi dalam Pembelajaran PKn di Sekolah Dasar." Laporan Penelitian, (tidak diterbitkan), IKIP Negeri Singaraja.

Linda, N. Eyre, Richard. 1995. Teaching Your Children Values. New York: Simon sand Chuster.

Likert, R. 1991. Organisasi Manusia. Terjemahan oleh P. Suratno. Jakarta: Erlangga.

Muslich, M. 2009. KTSP: Pembelajaran Berbasis Kompetensi dan Kontekstual. Jakarta: Bumi Aksara.

Purwanto, M. N. 2002. Psikologi Pendidikan. Bandung: PT Remaja Rosdakarya.

Poerwanti, E., Widodo, E., Masduki, Pamtiwati, Y., Rofieq, A., Uoto, D. P. 2008. Asesmen Pembelajaran SD. Jakarta: Departemen Pendidikan Nasional.

Raths, L.E., Harmin, M. dan Simon. 1978. Value and Teaching: Working With values in the Classrom. Second Edition. Columbus: Charles E. Merril Publishing Company.

Seifert, K. 2012. Pedoman Pembelajaran \& Instruksi Pendidikan. Diterjemahkan oleh Yusuf Anas. Jogyakarta: IRCiSoD.

Sarapung, N. E. 2010. "Penerapan Model Pembelajaran VCT Berbasis Multicultural Guna Meningkatkan Prestasi Belajar Agama Kristen pada Siswa SMAK Soverdin Tuban.” Tesis, Universitas Pendidikan Ganesha.

Sudiana, I N. 2010. "Pengaruh Metode Pembelajaran Teknik Klarifikasi Nilai (TKN) Terhadap Prestasi Belajar Pendidikan Kewarganegaraan Ditinjau dari Sikap Politik pada Siswa Kelas X di SMA Negeri 1 Petang.” Tesis, Universitas Pendidikan Ganesha,

Syah, M. 2011. Psikologi Belajar. Jakarta: Rajawali Press.

Umbara, S.P. 2011. "Pengaruh Penerapan Asesmen Proyek Terhadap Prestasi Belajar IPS Ditinjau dari Sikap Sosial (Studi Eksperimen pada Siswa Kelas VIII SMP Negeri Tegallalang).” Tesis, Universitas Pendidikan Ganesha.

Zuriah, N. 2008. Pendidikan Moral \& Budi Pkerti Dalam Perspektif Perubahan, Menggagas Platform Pendidikan Budi Pekerti Secara Kontekstual dan Futuristik. Jakarta: Bumi Aksara. 